Ann. Zootech., 1987, 36 (3), 271-290

\title{
Review
}

\section{Effect of beta-adrenergic agonists in animal production and their mode of action}

\author{
L.O. FIEMS \\ National Institute for Animal Nutrition \\ Agricultural Research Centre-Ghent \\ Scheldeweg 68, B-923I Melle-Gontrode (Belgium)
}

\begin{abstract}
Summary
Beta-adrenergic agonists cause a shift in carcass composition of poultry, pigs, cattle and sheep. Fat content is dramatically reduced in favour of a higher percentage of muscle. Carcass yield is usually enhanced and is accompanied by muscle hypertrophy. There is a tendency for an improved growth rate and feed conversion in poultry and ruminants. In pigs, only feed conversion was positively affected.

Beta-agonists alter metabolism of several important pathways. They possess lipolytic and antilipogenic properties and improve nitrogen retention. Glycolysis, lactate production and oxygen consumption are increased, while plasma insulin levels are decreased and adipocytes become less sensitive to insulin. Energy expenditure is increased by beta-agonists, partly due to an extra heat production.

In general, meat colour is not affected by beta-agonists. However, the increased metabolism resulted in a higher ultimate muscle $\mathrm{pH}$. Meat tenderness is mostly unaltered, but the carcass may be more susceptible to cold shortening due to a decreased fat cover. Proximate analysis of the whole ground carcass or individual muscles indicated less fat and more protein and moisture.
\end{abstract}

Key words : Beta-adrenergic agonists, growth, feed efficiency, carcass composition, metabolism.

\section{Introduction}

A major goal of animal husbandry has been the improvement in growth of meat producing animals. This goal can be achieved by different means. Breeds are characterized by different growth capacities. Hence, crossbreeding offers an opportunity to increase daily gain. Even in fast growing animals liveweight gain can be enhanced by feeding an appropriate diet. Besides selection and nutrition it is possible to modify the growth process with anabolic agents (GALBRAITH \& ToPPS, 1981). Furthermore, in nonruminant as in ruminant livestock production, antibiotics are largely used as feed additives for their growth promoting effect (VISEK, 1978 ; MACGreGor, 1983). Another approach to improve growth rate would be the auto-immunization against somatostatin (SPENCER et al., 1983), although the positive effect has not been confirmed (Galbraith et al., 1985). 
On the other hand, consumers are become more and more worried about dietary animal fats, which can be associated with atherosclerosis and heart disease in certain individuals.

There is the potential for beta-adrenergic agonists (BAA) to fulfil producers' and consumers' demands. Growth rate was improved by BAA in poultry (DALRYMPLE et al., 1984a and b), in cattle (HANRAHAN et al., 1986) and in sheep (BEermann et al., 1986a). Furthermore, carcass fatness in broilers, pigs, steers and lambs was dramatically reduced (DAlrymple et al., 1984b ; Jones et al., 1985 ; HANRAHAn et al., 1986 ; BAKer et al., 1984).

Several beta-adrenergic agonists including isoproterenol, fenoterol, clenbuterol (CL 263,521), cimaterol (CL 263,780), L-640,033, and BRL 35135 have been used in studies investigating their effects on animal performance. BAA may differ in selectivity and affinity for beta receptors (ARCH et al., 1984 ; MERSMANN, 1987). This paper will review these studies and discuss possible modes of action of BAA.

\section{Definition and origin}

An agonist is a compound that occupies a receptor and mimics the activity of a natural, biological mediator, usually in a more potent manner than the endogenous mediator. STiLEs et al. (1984) defined agonists as substances that maximally stimulate a system, with an intrinsic activity of 1 . In the case of adrenergic receptors, the action of the agonists is in relation with adrenalin and noradrenalin. Indeed, the chemical formula of BAA shows a strong similarity to adrenalin (fig. 1). BAA are chemically synthesized.

ADRENALIN

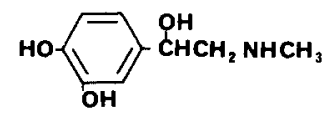

CLENBUTEROL

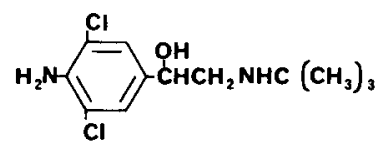

CIMATEROL

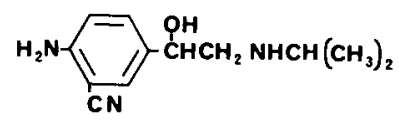

$\ell$-ISOPROTERENOL

F1G. 1

Chemical formula of adrenalin and some beta-adrenergic agents.

Formulc chimique de l'adrénaline et de quelques bêta-agonistes. 
Adrenergic receptors are cell membrane receptors, while other hormones exert their activity via nuclear or cytoplasmatic receptors (BLAIR, 1983). Two types of adrenergic receptors exist : $\alpha$ and $\beta$ receptors. $\beta$ receptors can be subdivided into $\beta 1$ and $\beta 2$ receptors and this is also true for $\alpha$ receptors (FAIN and GARCIA-SAINZ, 1983). Each of them has a typical function, and the ratio of $\beta 1$ to $\beta 2$-adrenergic receptors is quite variable in different organs, even within the same species (STILES et al., 1984). According to LANDS et al. (1967) $\beta 1$ receptors stimulate lipolytic and cardiac muscle acitivy, while $\beta 2$ receptors cause bronchodilatation and vasodepression through relaxation of smooth muscle. Recently the idea was put forth that there exists further subtypes of $\beta$ receptors, such as a $\beta 3$ receptor in brown adipose tissue (ARCH et al., 1984).

\section{Animal response to beta-adrenergic agonists}

\section{A. Effects in poultry}

Different BAA, such as cimaterol, clenbuterol (DALRYMPLE et al., 1984a and b) or L-640,033 (Muir et al., 1985) increased liveweight gain in broilers. They are incorporated in the diet at levels ranging from 0.125 to $2 \mathrm{ppm}$ for cimaterol (DaLRYMPLE et al., 1984a), 0.25 to $4 \mathrm{ppm}$ for clenbuterol (DALRYMPLE et al., 1984b) and 0.25 to $2 \mathrm{ppm}$ for L-640,033 (MUir et al., 1985).

Maximum growth rate improvement is observed with cimaterol at $0.25 \mathrm{ppm}$ (DALRYMPLE et al., 1984a) and 0.5 to $1 \mathrm{ppm}$ clenbuterol and L-640,033 (DALRYMPLE et al., 1984b ; MuIr et al., 1985). Besides gain, feed efficiency is also improved. Feed : gain ratio was 4 and $5 \%$ lower for $1 \mathrm{ppm}$ clenbuterol (DALRYMPLe et al., 1984b) and $10 \%$

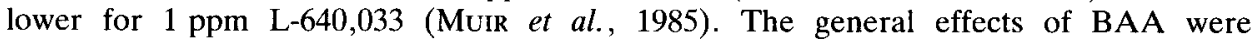
confirmed for different breeds : Hubbard chickens (Dalrymple et al., 1984b) and Arbor Acre $\times$ White Mountain (Muir et al., 1985).

Another effect of BAA is the enhanced dressing percentage, which was significantly higher than in control chickens (DALRYMPLE et al., 1984a and b). BAA reduce carcass fat content, as observed with cimaterol (DALRYMPLE et al., 1984a) as well as for clenbuterol (Dalrymple et al., 1984b). However, when the abdominal fat content was investigated, the amount was significantly reduced in female broilers but was not lowered in males (Dalrymple et al., 1984b). It is not clear why abdominal fat is unresponsive to BAA in males. The reduction in carcass fat is similar to the one observed in chickens after adrenalin infusion (Cunningham, 1963). Positive effects of clenbuterol are not nullified by the inclusion of a 3-day withdrawal period (DALRYMPLE et al., 1984b). Moisture content in meat is increased by the drug treatment (DALRYMPLE et al., 1984b). Effects of BAA on poultry performances are summarized in table 1.

Growth rate, feed conversion, dressing percentage and carcass fat content in treated animals amounted to $105,96,109$ and $90 \%$ of control animals, respectively.

\section{B. Effects in pigs}

Most experiments in pigs have been conducted with cimaterol (DALRYMPLE et al., 1984c ; Jones et al., 1985 ; Prince et al., 1985 ; Moser et al., 1986), with levels of 0.05, 
TABLE 1

Effect ${ }^{(*)}$ of different $\beta$-agonists on performance and carcass characteristics in broilers. Effet ${ }^{(*)}$ de différents $\beta$-agonistes sur les performances et les caractéristiques de carcasse chez les poulets de chair.

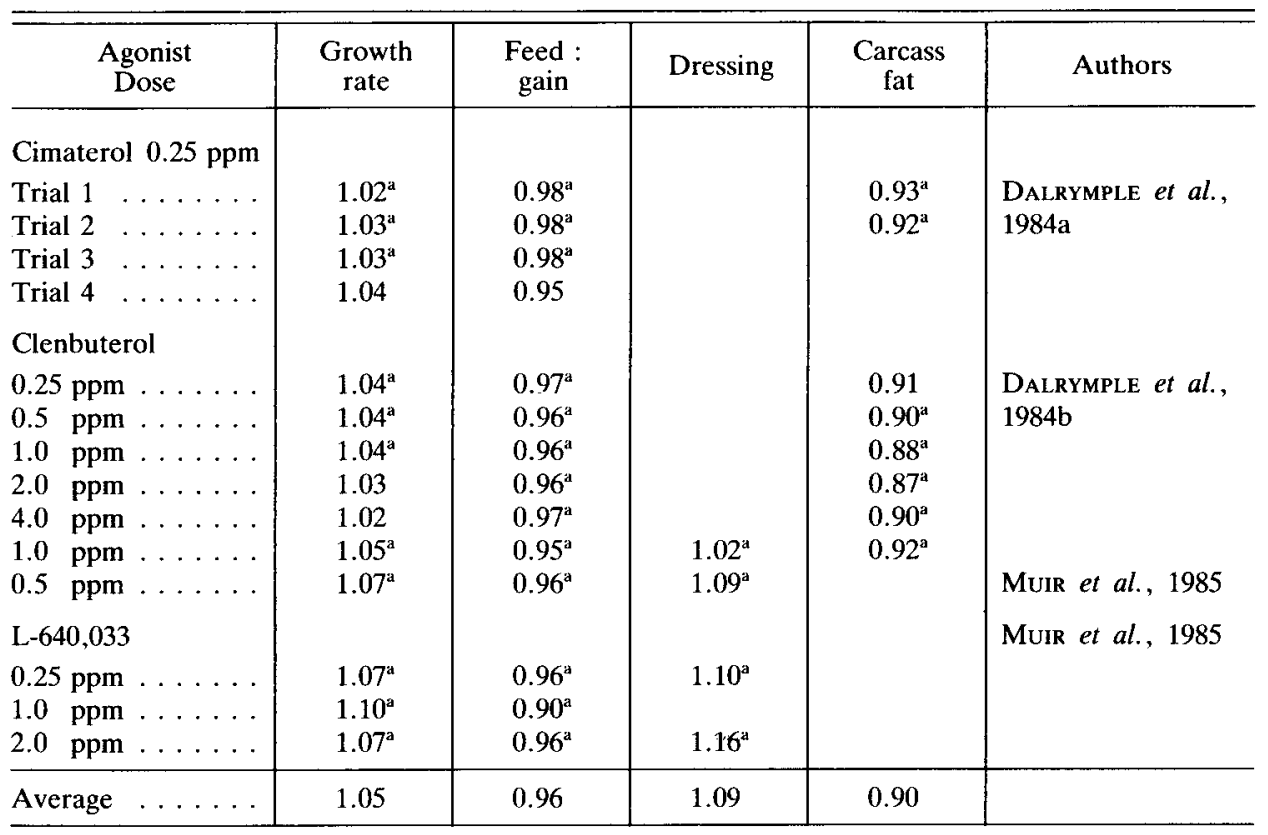

(*) Treated/control - Traité/témoin.

a : Significantly different from control $(P<0.05)$ - Significativement différent du témoin $(P<0.05)$.

$0.2,0.25,0.5$ and $1 \mathrm{ppm}$. Gain is not affected by cimaterol, except in a trial of DAlRYMPle et al. (1984c) where pigs fed 1 ppm grew significantly slower $(\mathrm{P}<0.05)$ than other animals. When clenbuterol was fed at $1 \mathrm{ppm}$ (RICKs et al., 1984a) daily gain of barrows was also reduced $(\mathrm{P}<0.05)$, but not for gilts. Rate gain was unaffected at lower levels. These findings are not in agreement with those observed with broilers, where gain was significantly increased by BAA.

Feed intake is reduced linearly $(\mathrm{P}<0.05)$ with increasing cimaterol levels (Jones et al., 1985 ; Prince et al., 1985 and Moser et al., 1986). Effects on feed efficiency were not always the same. Dalrymple et al. (1984c) and Moser et al. (1986) found no significant effect, while Jones et al. (1985) found a positive effect, but there was no apparent correlation of level of cimaterol to feed efficiency. PRINCE et al. (1985) found a slightly improved feed conversion, but the effect was not significant.

Dressing percent was not affected in experiments of Moser et al. (1986) and BEKAERT et al. (1987), while it was increased with $1 \mathrm{ppm}$ cimaterol (JoNEs et al., 1985). BAA always reduced backfat thickness (DALRYMPLE et al., 1984c ; Jones et al., 1985; MOSER et al., 1986). JoNes et al. (1985) observed muscle hypertrophy in pigs fed cimaterol. Semitendinosus and Biceps femoris muscles were 11.3 and $8.1 \%$ heavier, 
respectively. Moisture content in the semitendinosus muscle was slightly higher when pigs were fed cimaterol, and the effect reached significance between control and $0.5 \mathrm{ppm}$ combined with a 7-day withdrawal period. Cimaterol at $1 \mathrm{ppm}$ resulted in a significant depression of tenderness, but mostly, differences in Warner-Bratzler shear forces were negligible (JONEs et al., 1985). Colour of the longissimus muscle was not or hardly affected by cimaterol (JONES et al., 1985 ; MOSER et al., 1986 ; BEKAERT et al., 1987).

The withdrawal of cimaterol for 7 days resulted in a compensatory fat deposition (Jones et al., 1985). During the withdrawal period, pigs consumed $0.31 \mathrm{~kg}$ more feed per day than control animals, which helps to provoke the increased fat accretion.

The result obtained by Prince et al. (1985), with pigs fed 1 ppm cimaterol with 7day withdrawal did not reveal a complete compensatory effect on feed intake or backfat thickness, although both were increased, compared with $1 \mathrm{ppm}$ and no withdrawal period.

TABLE 2

Effect ${ }^{(*)}$ of cimaterol on performance and carcass characteristics in pigs.

Effet $^{(*)}$ du cimaterol sur les performances et les caractéristiques de carcasse chez les porcs.

\begin{tabular}{|c|c|c|c|c|c|}
\hline Dose & $\begin{array}{l}\text { Growth } \\
\text { rate }\end{array}$ & $\begin{array}{l}\text { Feed : } \\
\text { gain }\end{array}$ & Dressing & $\begin{array}{l}\text { Backfat } \\
\text { thickness }\end{array}$ & Authors \\
\hline $\begin{array}{l}0.05 \mathrm{ppm} \ldots \ldots \\
0.2 \mathrm{ppm} \ldots \ldots \\
1.0 \mathrm{ppm} \ldots \ldots\end{array}$ & & & & $\begin{array}{l}0.94 \\
0.95 \\
0.90\end{array}$ & $\begin{array}{l}\text { DALRYMPLE } \text { et al., } \\
1984 \mathrm{c}\end{array}$ \\
\hline $\begin{array}{l}0.25 \mathrm{ppm} \ldots \ldots \\
0.5 \mathrm{ppm} \ldots \ldots \\
1.0 \mathrm{ppm} \ldots \ldots\end{array}$ & $\begin{array}{l}1.05 \\
1.01 \\
1.04\end{array}$ & $\begin{array}{l}0.92^{\mathrm{a}} \\
0.91^{\mathrm{a}} \\
0.90^{\mathrm{a}}\end{array}$ & $\begin{array}{l}1.01 \\
1.01 \\
1.01^{\text {a }}\end{array}$ & $\begin{array}{l}0.92 \\
0.92 \\
0.87^{\mathrm{a}}\end{array}$ & JoNES et al., 1985 \\
\hline $\begin{array}{l}0.25 \mathrm{ppm} \ldots \ldots \\
0.5 \mathrm{ppm} \ldots \ldots \\
1.0 \mathrm{ppm} \ldots \ldots\end{array}$ & $\begin{array}{l}0.99 \\
0.99 \\
0.94\end{array}$ & $\begin{array}{l}0.98 \\
0.95 \\
0.98\end{array}$ & & $\begin{array}{l}0.94 \\
0.91 \\
0.90^{\mathrm{a}}\end{array}$ & Prince et al., 1985 \\
\hline $0.05 \mathrm{mg} / \mathrm{kg}$ weight & 1.02 & 0.99 & & 0.95 & $\begin{array}{l}\text { HANRAHAN et al., } \\
1986\end{array}$ \\
\hline $0.25 \mathrm{ppm}$ & 1.01 & 0.97 & 0.99 & $0.94^{\mathrm{a}}$ & Moser et al., 1986 \\
\hline $0.5 \mathrm{ppm}$ & 0.99 & 1.00 & 1.00 & $0.90^{\mathrm{a}}$ & \\
\hline $1.0 \mathrm{ppm} \ldots \ldots$ & 0.97 & 0.97 & 1.00 & $0.90^{\mathrm{a}}$ & \\
\hline Average $\ldots . \ldots$ & 1.00 & 0.96 & 1.00 & 0.92 & \\
\hline
\end{tabular}

(*) Treated/control - Traité/témoin.

a : Significantly different from control $(\mathrm{P}<0.05)$ - Significativement différent du témoin $(P<0.05)$.

\section{Effects in cattle and sheep}

The administration of 0.1 or $1 \mathrm{ppm}$ clenbuterol to veal calves did not affect liveweight gain, feed consumption and conversion of feed to gain (Williams et al., 1986). However, dressing percentage was significantly increased and fat deposition was reduced. 
Feeding $10 \mathrm{mg}$ clenbuterol per head per day to steers did not alter growth rate (Ricks et al., 1984b). However at $500 \mathrm{mg}$ clenbuterol per day liveweight gain was significantly reduced. Feed intake and feed conversion were not affected during an experimental period of 98 days. However, during the initial 56 days, both were significantly reduced. In other experiments with steers (HANRAHAN et al., 1986), with heifers (Coleman et al., 1986) and also with bulls (BoucQue et al., 1987), substantial improvements in growth rate and feed efficiency were obtained. Also in experiments with sheep daily gain was not significantly affected by clenbuterol or cimaterol (BAKER et al., 1984 ; BeERMAnN et al., 1986a). In other experiments (Dalrymple et al., 1985 ; BEERMANn et al., 1986a ; Kim et al., 1986) cimaterol significantly improved rate of gain.

Effect of BAA on feed conversion was variable. Substantial improvements were obtained with $100 \mathrm{ppm}$ clenbuterol but only in one experiment with $2 \mathrm{ppm}$ clenbuterol, as reported by BAKER et al. (1984). Feed conversion was not significantly affected in experiments of BAKER et al. (1984) when 1 and 10 or $0.5,2$ and $10 \mathrm{ppm}$ clenbuterol were incorporated in the diet for lambs. Dalrymple et al. (1985) also reported improvements with $0.5,2$ and $10 \mathrm{ppm}$ cimaterol and $2 \mathrm{ppm}$ clenbuterol. With crossbred lambs in a trial lasting 33 days, $10 \mathrm{ppm}$ cimaterol enhanced feed efficiency (BEERMaNN et al., 1986a). When the trial lasted 69 days, or when purebred Dorset wethers were involved, no effect was observed.

It is possible that the long-term administration of BAA reduces their positive effect on growth rate and feed conversion. Furthermore, breed differences may also affect the activity of BAA.

Clenbuterol did not improve dressing percent in Hereford steers, although there was a slight increase following the daily administration of $10 \mathrm{mg}$ (RIcks et al., 1984b). With Friesian steers and Belgian white-blue bulls dressing percentage was improved by more than four percent units (HANRAHAN et al., 1986 ; Boucque et al., 1987). Experiments of BAKER et al. (1984) and BEERMANN et al. (1986a) with lambs, fed clenbuterol and cimaterol respectively, revealed a significantly higher dressing percent for both drugs. These authors also reported muscle hypertrophy. These observations are in accordance with those obtained in pigs by Jones et al. (1985). HamBY et al. (1985) also found muscle hypertrophy in sheep caused by treatment with clenbuterol. In steers (Ricks et al., 1984b) and in lambs (Baker et al., 1984 ; Dalrymple et al., 1985 ; BEERMANN et al., 1986a) carcass composition was altered towards more protein and less fat. Results are summarized in table 3 .

\section{Effects in different strains of animals}

BERNE et al. (1985) reported that the effect of clenbuterol on muscle growth in laboratory rats was dependent on the strain of rat. Other reports wich confirm or deny these findings are scarce. In Southdown and Suffolk sired lambs SidHu et al. (1973) found a significant difference for basal lipolytic activity. However, the potential lipolytic activity after addition of $4 \mu \mathrm{M}$ cAMP, $40 \mu \mathrm{M}$ ATP and $133 \mu \mathrm{M} \mathrm{MgCl} \mathrm{Mg}_{2}$ resulted in an insignificant difference between breed groups. On the other hand, Gregory et al. (1977) reported a lower insulin-secreting ability and a lower sensitivity to exogenous insulin in Pietrain pigs than in Large White pigs. Moreover, BöcklEN et al. (1986) reported that the number of beta-adrenergic receptors was about 0.37 higher in Pietrain than in Large White pigs. This could account for an enhanced sensitivity to lipolytic agents in Pietrain pigs. Maybe this is valid in other species. In cattle, insulin levels are 


\section{TABle 3}

Effect ${ }^{(*)}$ of different $\beta$-agonists on performance and carcass characteristics in cattle and sheep. Effet $^{(*)}$ de différents $\beta$-agonistes sur les performances et les caractéristiques de carcasse chez les bovins et les moutons.

\begin{tabular}{|c|c|c|c|c|c|}
\hline $\begin{array}{l}\text { Agonist } \\
\text { Dose }\end{array}$ & $\begin{array}{l}\text { Growth } \\
\text { rate }\end{array}$ & $\begin{array}{l}\text { Feed : } \\
\text { gain }\end{array}$ & Dressing & $\begin{array}{l}\text { Carcass } \\
\text { fat }\end{array}$ & Authors \\
\hline \multicolumn{6}{|l|}{ Veal calves } \\
\hline $\begin{aligned} \text { Clenbuterol } & 0.1 \mathrm{ppm} \\
& 1.0 \mathrm{ppm} \ldots\end{aligned}$ & $\begin{array}{l}0.98 \\
0.97\end{array}$ & $\begin{array}{l}0.99 \\
1.04\end{array}$ & $\begin{array}{l}1.05^{\mathrm{a}} \\
1.07^{\mathrm{a}}\end{array}$ & $\begin{array}{l}0.85^{\mathrm{a}} \\
0.66^{\mathrm{a}}\end{array}$ & $\begin{array}{l}\text { WiLLIAMS et al., } \\
1986\end{array}$ \\
\hline \multicolumn{6}{|l|}{ Steers } \\
\hline Clenbuterol $10 \mathrm{mg} /$ day $\ldots$. & 0.92 & 1.01 & 1.01 & $0.80^{\mathrm{a}}$ & Ricks et al., 1984b \\
\hline Cimaterol : $\begin{array}{r}33.0 \mathrm{mg} / \text { day } \ldots \\
49.5 \mathrm{mg} / \text { day } \ldots \\
66.0 \mathrm{mg} / \text { day } \ldots\end{array}$ & $\begin{array}{l}1.18 \\
1.30 \\
1.06\end{array}$ & $\begin{array}{l}0.81 \\
0.77 \\
0.89\end{array}$ & $\begin{array}{l}1.08 \\
1.08 \\
1.09\end{array}$ & $\begin{array}{l}0.67^{\mathrm{a}} \\
0.62^{\mathrm{a}} \\
0.60^{\mathrm{a}}\end{array}$ & $\begin{array}{l}\text { HANRAHAN et al., } \\
1986\end{array}$ \\
\hline \multicolumn{6}{|l|}{ Heifers } \\
\hline Clenbuterol $10 \mathrm{mg} /$ day $\ldots \ldots$ & & 0.67 & & & $\begin{array}{l}\text { Coleman et al. } \\
1986\end{array}$ \\
\hline \multicolumn{6}{|l|}{ Bulls } \\
\hline Cimaterol 4 ppm $\ldots \ldots \ldots$ & 1.05 & 0.95 & $1.06^{\mathrm{a}}$ & $0.66^{\mathrm{a}}$ & $\begin{array}{l}\text { BoucQue et al., } \\
1987\end{array}$ \\
\hline \multicolumn{6}{|l|}{ Lambs } \\
\hline \multicolumn{6}{|l|}{ Clenbuterol } \\
\hline 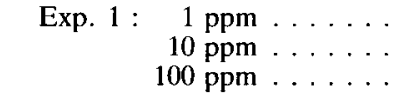 & $\begin{array}{l}0.92 \\
0.99 \\
1.07\end{array}$ & $\begin{array}{l}0.97 \\
0.92 \\
0.83^{\text {at }}\end{array}$ & $\begin{array}{l}1.06^{\mathrm{a}} \\
1.06^{\mathrm{a}} \\
1.02\end{array}$ & $\begin{array}{l}0.80^{\mathrm{a}} \\
0.73^{\mathrm{a}} \\
0.77^{\mathrm{a}}\end{array}$ & BAKER et al., 1984 \\
\hline 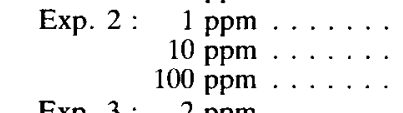 & $\begin{array}{l}1.10 \\
1.12 \\
1.10\end{array}$ & $\begin{array}{l}0.89 \\
0.85 \\
0.87\end{array}$ & $\begin{array}{l}1.07^{\mathrm{a}} \\
1.10^{\mathrm{a}} \\
1.07^{\mathrm{a}}\end{array}$ & $\begin{array}{l}0.77^{\mathrm{a}} \\
0.81^{\mathrm{a}} \\
0.77^{\mathrm{a}}\end{array}$ & \\
\hline $\begin{array}{c}\text { Exp. 3: } 2 \text { ppm } \ldots \ldots \ldots \\
\text { Clenbuterol } 10 \text { ppm } \ldots \ldots \ldots\end{array}$ & $\begin{array}{l}1.24^{\mathrm{it}} \\
1.07\end{array}$ & $\begin{array}{l}0.81^{\mathrm{a}} \\
0.83^{\mathrm{a}}\end{array}$ & $1.05^{\mathrm{a}}$ & & $\begin{array}{l}\text { BoHorov et al., } \\
1987\end{array}$ \\
\hline Cimaterol $10 \mathrm{ppm}$ & & & & & \\
\hline Exp. 1: $\begin{array}{r}7 \text { weeks } \ldots \ldots \\
12 \text { weeks } \ldots \ldots\end{array}$ & $\begin{array}{l}0.97 \\
0.99\end{array}$ & $\begin{array}{l}0.94 \\
0.92\end{array}$ & $\begin{array}{l}1.06^{\mathrm{a}} \\
1.08^{\mathrm{a}}\end{array}$ & & $\begin{array}{l}\text { BEERMANN et al. } \\
1986 \mathrm{a}\end{array}$ \\
\hline 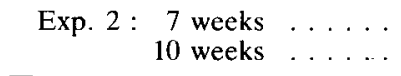 & $\begin{array}{l}1.13^{\mathrm{a}} \\
0.97\end{array}$ & $\begin{array}{l}0.83^{\mathrm{n}} \\
0.99\end{array}$ & $1.07^{\mathrm{a}}$ & & \\
\hline Overall mean & 1.06 & 0.89 & 1.06 & 0.73 & \\
\hline
\end{tabular}

(*) Treated/control - Traité/témoin

a : Significantly different from control $(\mathrm{P}<0.05)-$ Significativement différent du témoin $(P<0.05)$.

lower in double muscled animals than in conventional anımals (Michaux et al., 1982). Insulin and cAMP are involved in the activity of BAA. The mode of action is dealt with in the following section.

\section{E. Effect of age on efficacy of $B A A$}

The results presented in tables 1,2 and 3 must be interpreted with care, because a lot of experimental circumstances differ. In several species the performance response to 
BAA treatment is enhanced with animal maturity. Lambs with an initial weight of about $40 \mathrm{~kg}$ gained faster than controls when fed $2 \mathrm{ppm}$ clenbuterol, but the same dose had no effect on gain in lambs weighing initially $37.5 \mathrm{~kg}$ (BAKER et al., 1984). Also BEERMANN et al. (1986a) observed no effect of $10 \mathrm{ppm}$ cimaterol on growth rate in lambs weighing $17 \mathrm{~kg}$ at the onset of one experiment, while there was a significant effect of cimaterol in another experiment with lambs of about $28 \mathrm{~kg}$. In lambs with an initial weight of $27.6 \mathrm{~kg}$, BоHOROv et al. (1987) observed a tendency for a higher gain with clenbuterol, but the effect was not significant. Liveweight gain in steers of $530 \mathrm{~kg}$ was largely increased by cimaterol as reported by HANRAHAN et al. (1986), but there was no response of clenbuterol in steers of approximately $350 \mathrm{~kg}$ in experiments of Ricks et al. (1984). In veal calves growth rate was neither affected by clenbuterol (Williams et al., 1986). However, carcass fatness was always reduced in these investigations. Mersmann et al. (1987) could not detect any effect on carcass composition or adipose tissue metabolism in young pigs fed cimaterol between 10 and $60 \mathrm{~kg}$, which is in contradiction with the findings of Jones et al. (1985) and MOSER et al. (1986) in pigs between 60 and $105 \mathrm{~kg}$. In experiments of BEKAERT et al. (1987) cimaterol was fed either during the finishing period $(60-102 \mathrm{~kg}$ liveweight) or during the growing and finishing periods $(30-101 \mathrm{~kg})$. No extra effect was associated with the earlier administration of cimaterol. Also in rats this phenomenon has been observed. A marked muscle hypertrophy was observed in Sprague-Dawley rats, which were 6 weeks old at the start of the trial reported by ThiEL et al. (1987), but a smaller effect was obtained in 3-week old rats in experiments of BERNE et al. (1985).

Anticipating the mode of action, which is dealt with in the next section, several possibilities for a lack or a reduced effect of BAA in young animals can be suggested. The pharmacodynamical properties may be different at divergent ages. If absorption and metabolism of BAA differ in young and older species, then the optimal response dose in finishing animals may be too high or too low for young animals. Maybe the receptor number at young ages is too low. LAI et al. (1981) reported that $\beta$-receptor number increases by $60-70 \%$ by differentiation of 3T3-L1 preadipocytes into adipocytes. SMITH \& ClaRK (1980) found no difference in $\beta$-adrenergic receptor number in skeletal muscle in neonates and 8-week old rabbits and neither in the $\beta$-adrenergic receptor occupancy. Another hypothesis for the age-dependent efficacy of BAA is the alteration of the endocrine status. Maybe an increased effect of BAA in older animals can be related to a lower growth hormone secretion. Indeed, a decline in plasma growth hormone concentration with advancing age is documented in cattle (JoAKIMSEN \& Blom, 1976), lambs (Johnsson et al., 1985) and pigs (Machlin, 1972). If sex hormones are involved in the regulation of $\beta$-adrenergic receptors (STILEs et al., 1984), than the effect of BAA may be different before and after the onset of the puberty, and between males and females. Based on investigations with cimaterol WILSON et al. (1987) suggested that endogenous anabolic factors obscure the anabolic effect in younger animals, since significantly more tyrosine was converted to muscle protein in larger lambs, but not in smaller ones.

The effect of sex on the efficacy of BAA is not clearly demonstrated. However, in poultry, clenbuterol reduced abdominal fat pad and increased carcass protein in females only (DALRYMPLE et al., 1984b). In pigs, gain was reduced in barrows receiving $1 \mathrm{ppm}$ clenbuterol, but not in gilts (RICKs et al., 1984a). 


\section{Mode of action}

The presentation of data in table 1,2 and 3 is somewhat simplified, because breed, experimental period, initial age and weight and BAA were not similar in the involved experiments. Nevertheless, there is a striking uniformity in the effect of BAA on carcass composition. For all species and in all experiments, fatness was reduced. A shift in carcass composition was also observed in growing male rats (RICKES et al., 1985). This across species similarity indicates that the action of BAA occurs close to the basic control of lipid and protein metabolism. The effect is similar for oral and parenteral administration (DALRYMPLE et al., 1985 ; HANRAHAN et al., 1986). In comparison with anabolic steroids (GALBraith \& Topps, 1981), BAA exert a rapid effect and they are more generally active in different species of animals.

Although BAA are chemically synthesized, they possess some properties of catecholamines. The catecholamines adrenalin and noradrenalin are responsible for a set of functions : inhibition of insulin secretion, glycogenolysis, gluconeogenesis, lipolysis and enhanced glucagon secretion (McDowell, 1983). These functions may occur, for example, in situations of stress (Young, 1980 ; Brockman \& LaArveld, 1986). However, in cases of stress (cold, heat, fight, flight) exercise or hypocalcaemia, it is believed that catecholamines are emergency hormones, which provoke an immediate metabolic adaptation (homeostasis). When BAA are fed, they regulate basal metabolism via a phenomenon called "homeorhesis" (BAuman \& Currie, 1980). A new state of physiological equilibrium is formed with a repartitioning of nutrients.

Adrenalin is the most potent lipolytic agent in ruminants; noradrenalin is about $80 \%$ as potent (Brockman, 1986). It is supposed that lipolysis in ruminants and nonruminants occurs similarly, although it is suggested that ruminants are less sensitive to catecholamines than other species (VERNON, 1981). Catecholamines stimulate lipolysis by $2-10$ fold in ruminants, while a response of about 60 -fold is observed with rat adipose tissue. Other lipolytic agents may be glucagon and growth hormone (VERNON, 1981 ; DuQuetTe et al., 1984). In birds glucagon rather than catecholamines appears to be the dominant lipolytic hormone (BUTLER, 1975). The mechanism of lipolysis in adipose tissue through adrenalin or other adrenergic agents is shown in figure 2.

Via $\beta 1$ - and $\beta 2$ receptors adrenalin elevates cyclic adenosine $3^{\prime}, 5^{\prime}$ monophosphate (cAMP) through the stimulation of adenyl cyclase. cAMP is hydrolyzed by a phosphodiesterase to yield ordinary 5'-AMP. GTP plays a keyrole in the regulation of adenyl cyclase. It exerts a biphasic effect, i.e., activation is observed at low concentration whereas inhibition is produced at high concentration (FAIN \& Garcia-Sainz, 1983). A working model for the regulation on the adenyl cyclase by BAA is described by STiles et al. (1984). The intra-cellular effect of cAMP is the activation of a protein kinase, which in turn activates triglyceride lipase. Finally free fatty acids are released (Blum et al., 1982). This mechanism is inhibited by insulin, but it is not clear whether insulin stimulates the phosphodiesterase activity, or depresses the adenyl cyclase activity, or affects both processes (Siddle \& Hales, 1975 ; Vernon, 1981). Orcutt et al. (1986), reported that BAA reduce adipocyte sensitivity to insulin in the mouse. For this reason it is doubtful if BAA are equally effective in breeds which already have a lower sensitivity to insulin, e.g. in Pietrain pigs. According to Fain \& Garcia-Sainz (1983) it is probable that a decreased growth hormone secretion increases the cAMP phosphodiesterase activity. It is thought that BAA mediate metabolism through elevated 


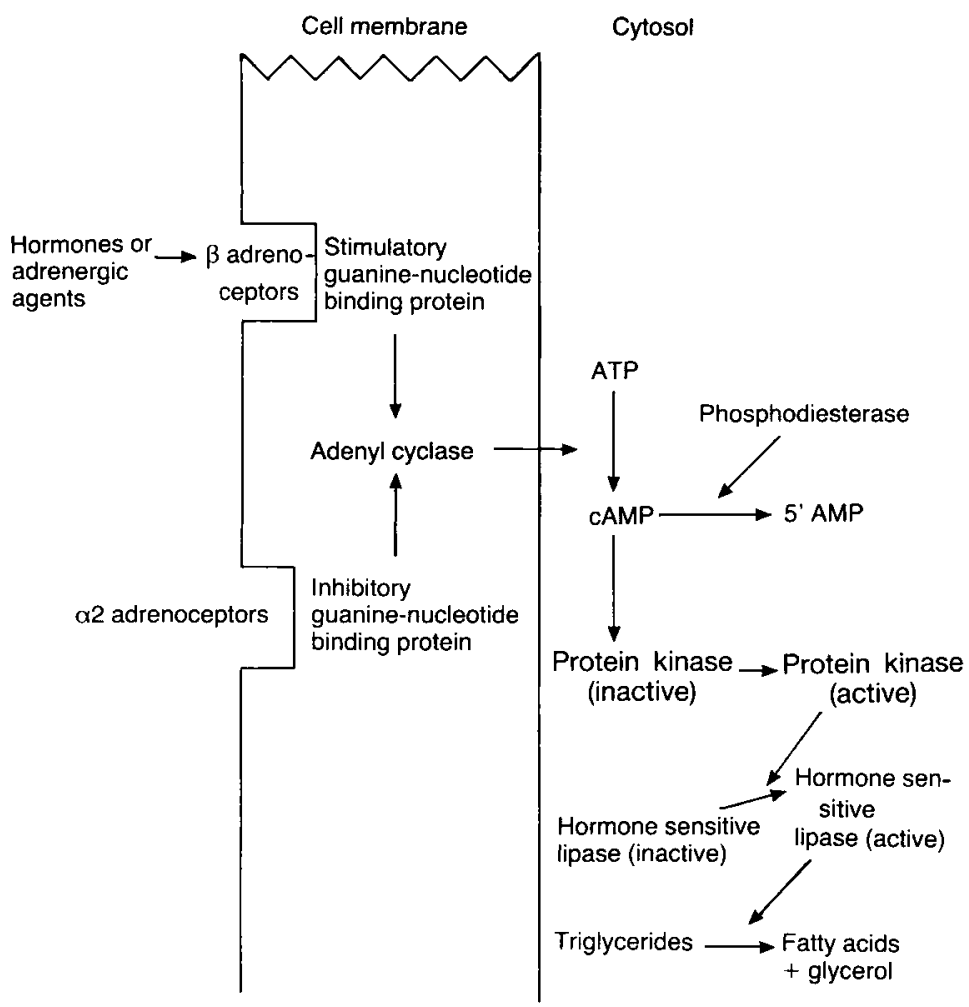

Fig. 2

Regulation of lipolysis in adipose tissue.

Régulation de la lipolyse dans le tissu adipeux.

cAMP levels (Stiles et al., 1984), similar to adrenalin. This means that adrenergic agonists are also potent metabolic regulators. From FaIN \& Garcia-SaInz (1983) it appears that BAA may differ in their ability to activate adenyl cyclase.

Effect of BAA on carcass composition acts through different pathways. As a result of lipolysis, carcass fat is reduced. Although lipolysis is stimulated by glucagon in birds, there may be an indirect effect of BAA as they stimulate glucagon secretion. Sheep metabolism studies of COLEMAN et al. (1985) indicated that fat accretion was reduced by a decrease in total fat cell number. Obviously, fat reduction occurs through a depressed lipogenesis in subcutaneous adipose tissue in heifers, but not in intramuscular adipose tissue (Coleman et al., 1986 ; Miller et al., 1986). An inhibition of the uptake and esterification of fatty acids by clenbuterol in ovine adipose tissue was previously reported by THORNTON et al. (1985), together with an increased lipolysis. The effect of clenbuterol on lipolysis was observed in vivo as well as in vitro. Clenbuterol did not stimulate porcine adipose tissue lipolysis in vitro, but increased plasma free fatty acid and blood glycerol concentrations when infused in pigs (MersmanN, 1987). These observations indicate that the mechanism in vivo may vary between species : an indirect effect in pigs and a direct or a direct and an indirect effect in sheep. 
Experiments of DUQuETTE \& MUIR (1985) demonstrated that some BAA agents are more anti-lipogenic than lipolytic, or are equal in lipolytic and anti-lipogenic activity. This anti-lipogenic function is of greater interest in growing animals than the lipolytic function. Indeed, in early growth 50 to $60 \%$ of the deposited energy is protein, the remainder is fat. In later stages of growth, fat becomes more predominant and near maturity 85 to $90 \%$ of the energy deposit is fat (VAN Es, 1977). Consequently, an inhibition of fat accretion is more opportune than lipolysis for meat animals which approach maturity.

On the other hand muscle hypertrophy has usually been observed. Increased hypertrophy is associated with an increase in the diameter of type II fibres according to Coleman et al. (1986), HambY et al. (1986), Кim et al. (1986) and Wu et al. (1986), although BEERMANN et al. (1985c) reported a hypertrophy of both type I and II fibres. A marked hypertrophy of the soleus muscle in rats was found in experiments of REEDS et al. (1986), Thiel et al. (1987) and Zeman et al. (1987), and this muscle is characterized by a high percentage of type I fibres. Recently, KIM et al. (1987a and b) observed that cimaterol feeding in rats and lambs caused hypertrophy of both type I and type II fibres, but the increase of type II fibres was twice to three times greater than type I fibres. The proportion of type I and type II fibres in lambs was unaffected by cimaterol (KIM et al., 1986). This means that hypertrophy induced by BAA is not completely similar to hypertrophy of genetic origin, where type II fibres have a larger size and their number is increased (WEST, 1974).

The shift in carcass composition and the hypertrophy of type II muscle fibres may alter the metabolism. It is known that lean tissue is more metabolically active than fat tissue (Mrtchell, 1962). Muscle hypertrophy coincided with an increased nitrogen retention, both as a measure of an increased muscle protein accretion (BEERMANN et al., 1986b ; Macrae et al., 1986 ; Williams et al., 1986). Extra protein deposition in rats was due to an increased synthesis by 34 and $26 \%$ following the administration of clenbuterol and fenoterol (EMERY et al., 1984). No increased synthesis, but a reduced protein degradation was reported by LI \& JeFFERSON (1977) for isoproterenol. ReEDS \& Palmer (1986) stated that protein synthesis and degradation rise or fall in concert, when muscle growth is altered. This means that the increased protein deposition requires only an increase in the difference between the rates of synthesis and degradation. Effects of clenbuterol obtained with mice (RoTHWELL \& STOcK, 1985), with rats (ReEds et al., 1986 ; ZEMAN et al., 1987) and with lambs (BoHORov et al., 1987) provide evidence that protein degradation rate is reduced by BAA. According to McElligotT and coworkers, quoted by Ricks (1987), the inhibitory effect on protein degradation may be mediated via a decrease in lysosomal proteolytic enzymes.

Other indications of an increased metabolism, observed in treatments with BAA, are increased rates in lactate production, muscle glycogen breakdown to $\mathrm{CO}_{2}$ and oxygen consumption (Li \& JEFFERSON, 1977 ; HAMBY et al., 1985). Apparently, there is also a transient increase in heart rate (BLum et al., 1982 ; BEERMANN et al., 1986a and b ; Mersmann, 1987) and arterial blood flow (BeERMAnN et al., 1986c). The greater cardiac acitivity is more a side effect of $\beta 2$ agonists, because it is $\beta 1$ specific (LANDS et al., 1967). BAA may also be responsible for increasing thermogenesis (Rothwell et al., 1983 ; Beermann et al., 1986a ; Macrae et al., 1986). Williams et al. (1986) calculated a $12 \%$ higher heat production when veal calves were given $1 \mathrm{mg}$ clenbuterol per $\mathrm{kg}$ diet. The increased heart rate and thermogenesis can be responsible for the increased energy expenditure of $16 \%$, observed with rats fed $1 \mathrm{ppm}$ clenbuterol (Rothwell et al., 1984). КIM et al. (1987c) stated that cimaterol increased energy 
requirement for maintenance from 0.39 to $0.46 \mathrm{MJ}$ metabolizable energy per $\mathrm{kg} \mathrm{W}$ 0.75 .

The effect of BAA on growth rate is less clear than the effect on carcass composition. On average, gain was not improved in pigs, while there was an increase of $5 \%$ in broilers and $6 \%$ in cattle and sheep for the experiments summarized in tables 1 to 3. BAKER, quoted by Ricks et al. (1984b), found higher serum growth hormone levels in sheep treated with clenbuterol. In such a case higher gains can be expected (BAUMAN, 1984). However, no significant changes were recorded in plasma growth hormone during a 4-day period of adrenalin infusion in lactating ewes (MCDowELL, 1983). BEERMANN et al. (1985b) found increased concentrations of thyroid hormones and lower insulin concentrations in the plasma of wether lambs treated with $10 \mathrm{ppm}$ cimaterol. Thyroid hormones regulate somatomedin receptors, and thereby growth (Spencer, 1985). Moreover Fain \& Garcia-Sainz (1983) and Stiles et al. (1984) stated that lipolytic activity in adipose tissue is modulated by thyroid hormones. Adipocytes from hyperthyroid animals display an increased sensitivity to all lipolytic hormones including catecholamines, and the opposite is true for cells of hypothyroid animals. However, plasma levels of growth hormone and triiodothyronine were unaffected by chronic clenbuterol treatment in rats (EMERY et al., 1984). There is also evidence that glucocorticoids are necessary for the growth promoting and the nutrient partitioning actions of BAA (ShARPE et al., 1986). Stiles et al. (1984) suggested that adrenal corticosteroids are able to regulate both the number of $\beta$-adrenergic receptors and their coupling to the adenylate cyclase system via the guanine nucleotide regulatory protein. These authors also stated that sex hormones may be involved in the dynamic regulation of $\beta$-adrenergic receptors.

It is difficult to explain the conflicting results of RICKs et al. (1984b), where the level of growth hormone was increased, and those of MCDowell (1983) and EMERY et al. (1984), where levels were unaffected. It may be possible that the growth hormone level is reduced to normal values at the moment of sampling (16 days after the start of the clenbuterol administration) in the experiment of EMERY et al. (1984). Indeed, REEDS et al. (1986) reported that the growth promoting effect became less with time, resulting in a fractional rate of muscle growth which was similar in tested and control rats. A decreased growth stimulation was also obtained by BoucQue et al. (1987) in bull beef production trials. PERKINS et al. (1985) found an evanescent effect of BAA on the secretion rate of growth hormone. Nevertheless, the release of growth hormone from rat anterior pituitary cells in vitro was clearly stimulated by BAA in experiments of PERKINs et al. (1983 and 1985) and SwENNEN et al. (1985). This results are confirmed by in vitro experiments where clenbuterol at 10 and $100 \mu \mathrm{M}$ stimulated growth hormone release of bovine adenohypophyseal cells by 2.7 and 14.8 fold, respectively, relative to control (Welsh et al., 1987). BeERMANn \& Hogue (1986d) determined plasma concentrations of growth hormone in cimaterol fed lambs at 6 and 12 weeks. Growth hormone concentration was about $50 \%$ higher $(\mathrm{P}<0.01)$ in treated animals at 6 weeks, but it was not different at 12 weeks. With regard to growth hormone, we have already mentioned a declined plasma concentration with advancing age.

Once again, species differences can be suggested. Perkins et al. (1985) found receptors of the $\beta 2$-subtype in the rat anterior pituitary, but in contrast, porcine anterior pituitary contained $\beta$ 1-adrenergic receptors. STILES et al. (1984) described an agonist specific tachyphylaxis. This phenomenon may explain the transient stimulation of growth hormone release reported by PERKINs et al. (1985). Furthermore, it remains to be demonstrated how in vitro and in vivo results are to be reconciled. 


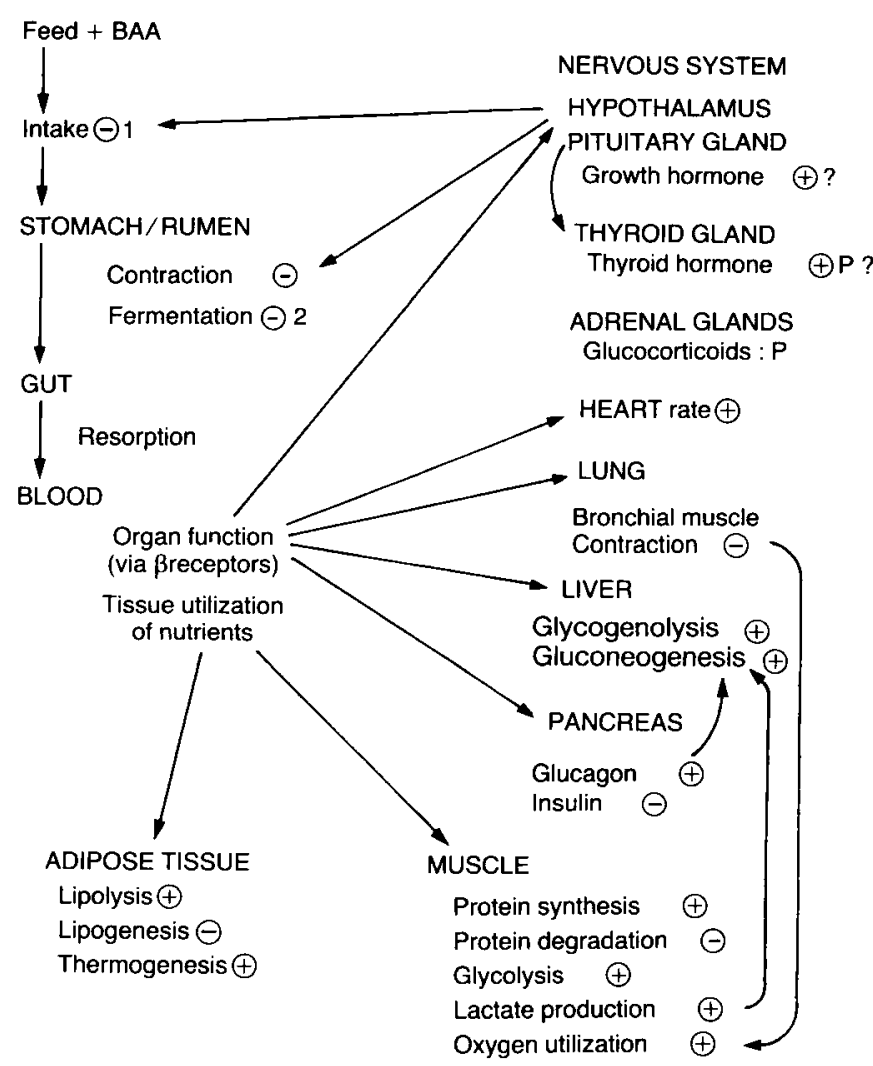

FIG. 3

Effect of $\beta$-agonists (BAA) on the action of different organs and tissues.

Mode d'action possible des $\beta$-agonistes sur différents organes ou tissus.

$\Theta$ : inhibition by BAA, $\odot$ : stimulation by BAA, ? : synergistic or consecutive effect not yet clear, 1 : species dependent, $2:$ dose dependent, $P$ : permissive effect on $\beta$-agonists.

In some experiments, especially with pigs (Jones et al., 1985 ; MOSER et al., 1986), feed intake was significantly depressed. This phenomenon is in agreement with earlier findings of Cunningham et al. (1963) where daily injections of adrenalin in young pigs reduced feed intake and growth rate. Results of LeIBowITZ (1970) obtained with rats, deprived of feed for 18 hours, clearly demonstrate that BAA, injected directly into the hypothalamus, suppressed food intake. However the effect of different BAA on eating behaviour seems to be divergent for different species of animals. BAILE et al. (1972) demonstrated that cerebroventricular injections of $\mathrm{dl}$-isoproterenol- $\mathrm{HCl}$ in satiated sheep and steers resulted in an increased feed intake. However higher doses provoked anorexia in sheep, but not in steers. A high dosage level of $500 \mathrm{mg}$ per day, administrated as a top-dressing to the diet, reduced feed intake in steers, but only during the first 56 days of the treatment (Ricks et al., 1984b). Graham et al. (1982) found a decreased rumen motility in sheep infused with adrenalin. If rumen motility is decreased, a lower rate of passage could be expected, resulting in an improved 
digestibility. However, no effect on digestibility in sheep was observed when cimaterol was incorporated in the diet (Boucoue et al., 1987 ; KIM et al., 1987c). Ricks et al. (1984b) observed a significant reduction in total rumen volatile fatty acid concentration in steers fed $500 \mathrm{mg}$ clenbuterol per day, a dosage of fifty times the use level. It was not determined whether the lower volatile fatty acid concentration was the result of a reduced rumen fermentation or a faster uptake of the fatty acids. This negative effect was not reported for $100 \mathrm{mg}$ clenbuterol per head per day (RICKs et al., 1984b) or $4 \mathrm{ppm}$ cimaterol (BoucQue et al., 1987). Experiments with pigs (CunNingham et al., 1963) did not reveal an altered digestibility due to adrenalin infusions.

The increased metabolism and the hypertrophy of type II muscle fibres may affect meat quality. Hypertrophy of white fibres, provoked by clenbuterol in heifers (ColeMAN et al., 1986), could result in a paler meat. The darkness value for the longissimus muscle in lambs fed cimaterol was lower (BEERMANN et al., 1985a). However, experiments with pigs (JoNes et al., 1985 ; MOSER et al., 1986) did not reveal differences in colour between control and treatment groups.

Because type II muscle fibres are more glycolytic than type I fibres, muscle pH could be decreased. Nevertheless higher muscle $\mathrm{pH}$ values were reported in lambs fed cimaterol (BEERMANN et al., 1985a), probably due to lower glycogen levels (see above).

As carcasses contain less subcutaneous fat when treated with BAA, they may be more susceptible to cold shortening (MARSH, 1975), which decreases meat tenderness. Tenderness was unaltered in lambs when they received cimaterol (BEERMANN et al., 1985a). In pigs Warner-Bratzler shear force values were slightly higher for cimaterol treated animals (JoNEs et al., 1985). The higher shear force values obtained in lambs with the clenbuterol treatment (НАмвY et al., 1985) were attributed to cold shortening, but other factors could also be involved. On the other hand, BAA may also improve meat tenderness. BAA increase muscle thickness, and as a result the connective tissue component of muscle structure could be decreased (Dumont, 1978).

Moisture content was mostly increased by BAA, in the hindquarters of sheep (BAKer et al., 1984), in the carcass of steers (RICKs et al., 1984b), in the meat of pigs (Jones et al., 1985) and in the carcass of poultry (DALRYMPLe et al., 1984b). The higher moisture content is not a direct consequence of the application of BAA, but is due to the higher protein content and the fact that the water retention amounts to about 3 gram per gram of protein (VAN Es, 1976 ; ROBELIN and GEAY, 1978).

Some possible modes of action of BAA are schematized in figure 3 .

\section{Conclusion}

BAA are powerful compounds which cause a significant repartition of feed energy into more carcass lean tissue. As such they fulfil the consumer's demand for a leaner meat product. In addition, feed costs can be reduced through improved animal performance. However, an enhanced growth rate and a more efficient feed conversion were not always observed. An altered metabolism is the basis for these effects. Although some studies are available which deal with the mode of action of BAA, there is no complete clarity about the effect on lipolysis and liveweight gain. 
More experiments with BAA are necessary to look at the response of different animal species, animal maturity, breed and sex, to determine the optimal dose and duration of application, to study the impact of dietary energy and protein levels and to investigate the compensatory effects after withdrawal of BAA.

\section{Reçu en février 1987.}

Accepté en août 1987.

\section{Résumé \\ Effet des agonistes bêta-adrénergiques en production animale et leur mode d'action}

Les bêta-agonistes provoquent un changement de la composition de la carcasse chez les volailles, les porcs, les bovins et les agneaux. La quantité de graisse est fortement réduite en faveur d'un pourcentage de muscles augmenté. Le rendement à l'abattage est élevé et accompagné d'une hypertrophie musculaire. On constate une tendance à l'amélioration de la croissance et de l'indice de consommation chez les volailles et les ruminants. Chez les porcs, l'indice de consommation n'est qu'amélioré.

Les bêta-agonistes modifient le métabolisme par différents processus. Ils possèdent des propriétés lipolytiques et anti-lipogènes et augmentent la rétention d'azote. La glycolyse, la production lactique et la consommation d'oxygène sont élevées. La concentration d'insuline du plasma est réduite et les cellules adipeuses sont moins sensibles à l'insuline. La consommation d'énergie est augmentée, en partie à cause d'une production de chaleur plus élevée.

En général, la couleur de la viande n'est pas modifiée par les bêta-agonistes. Néanmoins, le changement du métabolisme a donné lieu à des muscles à $\mathrm{pH}$ élevé. Le plus souvent la tendreté n'est pas influencée, mais la carcasse peut être plus sensible à la contraction au froid du fait d'une couverture de graisse inférieure. L'analyse des carcasses entières ou des muscles individuels indique moins de graisse et davantage d'azote et d'eau.

Mots clés: Agonistes bêta-adrénergiques, croissance, efficacité alimentaire, composition de carcasse, métabolisme.

\section{References}

Arch J.R.S., Ainsworth A.T., Cawthorne M.A., Piercy A., Sennitt, M.V., Thody V.E., WILSON C., Wilson S., 1984. Atypical beta-adrenoceptor on brown adipocytes as target for anti-obesity drugs. Nature, 309, 163-165.

Baile C.A., Simpson C.W., Krabill L.F., Martin F.H., 1972. Adrenergic agonists and antagonists and feeding in sheep and cattle. Life Sci., 11, 661-668.

Baker P.K., Dalkymple R.H., Ingle D.L., Ricks C.A., 1984. Use of a $\beta$-adrenergic agonist to alter muscle and fat deposition in lambs. J. Anim. Sci., 59, 1256-1261.

Bauman D.E., 1984. Effect of growth hormone on growth rates and mammary development of ruminants. Proc. Cornell Nutr. Conference, pp. 13-17.

Bauman D.E., Currie W.B., 1980. Partitioning of nutrients during pregnancy and lactation : A review of mechanisms involving homeostasis and homeorhesis. J. Dairy Sci., 63, 1514-1529.

Beermann D.H., Fishell V.K., Hogue D.E., Dalrymple R.H., 1985a. Effects of cimaterol (CL 263,780 ) and fishmeal on postmortem $\mathrm{pH}$, tenderness and color in lamb skeletal muscle. $J$. Anim. Sci., 61, Suppl. 1:271 (Abstr.).

Beermann D.H., Butler W.R., Hogue D.E., Dalrymple R.H., Ricks C.A., 1985b. Plasma metabolic hormone, glucose and free fatty acid concentration in lambs fed the repartitioning agent, cimaterol (CL 263,780). J. Anim. Sci., 61, Suppl. 1: 255 (Abstr.). 
Beermann D.H., Fishell V.K., Hogue D.E., Ricks C.A., Dalrymple R.H., 1985c. Effects of the repartitioning agent, cimaterol (CL 263,780) on skeletal muscle fiber type and fiber hypertrophy in lambs. J. Anim. Sci., 61: Suppl. 1: 254 (Abstr.).

Beermann D.H., Hogue D.E., Fishell V.K., Dalrymple R.H., Ricks C.A., 1986a. Effects of cimaterol and fishmeal on performance, carcass characteristics and skeletal muscle growth in lambs. J. Anim. Sci., $62: 370-380$.

Beermann D.H., Reeds P.J., Deb Hovell F.D., Kyle D., 1986b. Cimaterol elicits rapid physiological responses in growing lambs wholly nourished by intragastric infusion. J. Anim. Sci., 63, Suppl. 1 : 240 (Abstr.).

Beermann D.H., Butler W.R., Fishell V.K., Bergman E.N., McCann J.P., 1986c. Preliminary observations on the effects of cimaterol on heart rate, blood flow, plasma insulin concentration and net glucose uptake in the hindquarters of growing lambs. J. Anim. Sci., 63, Suppl. $1: 225$ (Abstr.).

Beermann D.H., Hogue D.E., 1986d. Effect of cimaterol and fishmeal on body composition and skeletal muscle growth in lambs. Proc. Cornell Nutrition Conference, pp. 29-38.

Bekaert H., Casteels M., Buysse F.X., 1987. Effects of a $\beta$-agonist cimaterol on performance, carcass- and meat quality of growing-finishing pigs of the Belgian landrace. Proc. EECseminar on "Beta-agonists and their effects on animal growth and carcass quality", Brussels, 19-20 May (in press).

Berne R.S., Novakofski J., Bechtel P.J., 1985. Effects of the $\beta$-agonist clenbuterol on body and tissue weights in four strains of rats. J. Anim. Sci., 61, Suppl. 1: 256 (Abstr.).

Blair E.L., 1983. Hormones and metabolism: a background. Proc. Nutr. Soc., 42, 103-111.

Blum J.W., Froehli D., Kunz P., 1982. Effects of catecholamines on plasma free fatty acids in fed and fasted cattle. Endrocrinology, 110, 452-456.

Böcklen E., Flad S., Müller E., Von Faber H., 1986. Comparative determination of betaadrenergic receptors in muscle, heart and backfat of Piétrain and Large White pigs. Anim. Prod., 43, 335-340.

Bohorov O., Buttery P.J., Correia J.H.R.D., Soar J.B., 1987. The effect of the $\beta$-2-adrenergic agonist clenbuterol or implantation with oestradiol plus trenbolone acetate on protein metabolism in wether lambs. Br. J. Nutr., 57, 99-107.

Boucque Ch.V., Fiems L.O., Sommer M., Cottyn B.G., Buysse F.X., 1987. Effects of the betaagonist cimaterol on growth, feed efficiency and carcass quality of finishing white-blue beef bulls. Proc. EEC-seminar on "Beta-agonists and their effects on animal growth and carcass quality ", Brussels, 19-20 May (in press).

Brockman R.P., 1986. Pancreatic and adrenal hormonal regulation of metabolism. in : Control of digestion and metabolism in ruminants. Ed. by L.P. Milligan, W.C. Grovum and A. DoBson, Prentice-Hall, Engelwood Ciffs, U.S.A., pp. 405-419.

Brockman R.P., Laarveld B., 1986. Hormonal regulation of metabolism in ruminants ; a review. Livest. Prod. Sci., 14, 313-334.

ButLER E.J., 1975. Lipid metabolism in the fowl under normal and abnormal circumstances. Proc. Nutr. Soc., 34, 29-34.

Coleman M.E., Ekeren P.A., Smith S.B., 1985. Adipose tissue metabolism in sheep fed the repartitioning agent clenbuterol. J. Anim. Sci., 61, Suppl. 1: 264 (Abstr.).

Coleman M.E., Ekeren P.A., Lunt D.K., Smith S.B., 1986. Muscle and adipose tissue development in heifers fed the beta-agonist clenbuterol. J. Anim. Sci., 63, Suppl. $1: 3$ (Abstr.).

Cunningham H.M., 1963. Effects of epinephrine, norepinephrine and nicotine on growth and carcass composition of chicks. Poult. Sci., 42, 1197-1202.

Cunningham H.M., Friend D.W., Nicholson J.W.G., 1963. Effect of epinephrine on nitrogen and fat deposition in pigs. J. Anim. Sci., 22, 632-636.

Dalrymple R.H., Gingher P.E., Ingle D.L., Maddock H.M., Pensack J.M., Ricks C.A., Goodwin T.L., Waldrup P.W., 1984a. Use of the repartitioning agent AC 263,780 to improve performance and carcass characteristics in broilers. Poult. Sci., 63, Suppl. 1: 85 (Abstr.).

Dalrymple R.H., Baker P.K., Gingher P.E., Ingle D.L., Pensack J.M., Ricks C.A., 1984b. A repartitioning agent to improve performance and carcass composition of broilers. Poult. Sci., 63, 2376-2383. 
Dalrymple R.H., Baker P.K., Doscher M.E., Ingle D.L., Pankavich J.A., Ricks C.A., 1984c. Effect of the repartitioning agent $\mathrm{CL} 263,780$ on muscle and fat accretion in finishing swine. J. Anim. Sci., 59, Suppl. 1: 212 (Abstr.).

Dalrymple R.H., Baker P.K., Doscher M.E., Ingle D.L., Ricks C.A., 1985. Effect of the repartitioning agent cimaterol (CL 263,780) on growth and carcass characteristics of lambs. $J$. Anim. Sci., 61, Suppl. 1 : 256 (Abstr.).

Dumont B.L., 1978. Variation and impact of muscle thickness. In : Patterns of growth and development in cattle. Ed. by H. DE Boer \& J. Martin, M. Nijhoff, The Hague, pp. 133-147.

Duquette P.F., Scanes C.G., Muir L.A., 1984. Effects of ovine growth hormone and other anterior pituitary hormones on lipolysis of rat and ovine adipose tissue in vitro. J. Anim. Sci., 58, 1191-1197.

DuqueTte P.F., Muir L.A., 1985. Effect of the beta-adrenergic agonists isoproterenol, clenbuterol, L-640,033 and BRL 35135 on lipolysis and lipogenesis in rat adipose tissue in vitro. J. Anim. Sci., 61, Suppl. 1: 265 (Abstr.).

Emery P.W., Rothwell N.J., Stock M.J., Winter P.D., 1984. Chronic effects of beta-agonists on body composition and protein synthesis in the rat. Biosci. Rep., 4, 83-91.

FaIN J.N., Garcia-Sainz J.A., 1983. Adrenergic regulation of adipocyte metabolism. J. Lipid Res., 24, 945-966.

Galbraith H., TopPs J.H., 1981. Effect of hormones on the growth and body composition. Nutr. Abstr. Rev., Ser. B., 51, 521-540.

Galbraith H., Wigzell S., Scaife J.R., Henderson G.D., 1985. Growing and metabolic response of rapidly growing male castrate lambs to immunization against somatostatin. Anim. Prod., 40, 523 (Abstr.).

Graham A.D., Nicol A.M., Christopherson R.J., 1982. Rumen motility responses to adrenaline and noradrenaline and organ weights of warm- and cold-acclimated sheep. Can. J. Anim. Sci., 62, 777-786.

Gregory N.G., Lovell R.D. Wood J.D., Lister D., 1977. Insulin-secreting ability in Pietrain and Large White pigs. J. agric. Sci., Camb., 89, 407-413.

Hamby P.L., Stouffer J.R., Smith S.B., 1985. Muscle metabolism and carcass traits in lambs fed diets containing a beta-agonist. J. Anim. Sci., 61, Suppl. 1: 246 (Abstr.).

Hamby P.L., Stouffer J.R., Sмith S.B., 1986. Muscle metabolism and real-time ultrasound measurement of muscle and subcutaneous adipose tissue growth in lambs fed diets containing a beta-agonist. J. Anim. Sci., 63, 1410-1417.

Hanrahan J.P., Quirke J.F., Bomann W., Allen P., McEwan J., Fitzsimons J., Kotzian J., Roche J.F., 1986. $\beta$-agonists and their effect on growth and carcass quality. In : Recent advances in animal nutrition. Ed. by W. HARESIGN and D.J.A. Cole, Butterworths, London, pp. 125-138.

JoAKImSEN O., BLom A.K., 1976. Growth hormone concentration in jugular blood plasma in relation to growth rate and age in young bulls. Acta. Agric. Scand., 26, 239-242.

Johnsson I.D., Hart I.C., Simmonds A.D., Morant S.V., 1985. Pre-pubertal mammogenesis in the sheep. 2. The effects of level of nutrition on the plasma concentrations of growth hormone, insulin and prolactin at various ages in female lambs and their relationship with mammary development. Anim. Prod., 41, 333-340.

Jones R.W., Easter R.A., McKeith F.K., Dalrymple R.H., Maddock H.M., Bechtel P.J., 1985. Effect of the $\beta$-adrenergic agonist cimaterol (CL 263-780) on the growth and carcass characteristics of finishing swine. J. Anim. Sci., 61, 905-913.

Kim Y.S., LeE Y.B., Ashmore C.R., 1987a. Cimaterol-induced growth in rats : growth pattern and biochemical characteristics. J. Anim. Sci., 65, Suppl. 1 : 251 (Abstr.).

Kim Y.S., Lee Y.B., Ashmore C.R., Dalrymple R.H., 1986. Effect of the repartitioning agent, cimaterol (CL 263,780), on growth, carcass characteristics and skeletal muscle cellularity of lambs. J. Anim. Sci.1, 63, Suppl. 1: 221 (Abstr.).

Kim Y.S., LeE Y.B., Ashmore C.R., Dalrymple R.H., 1987b. Effect of cimaterol on skeletal muscle characteristics of lambs. J. Anim. Sci., 65, Suppl. 1 : 278 (Abstr.).

Kim Y.S., Lee Y.B., Garrett W.N., Dalrymple R.H., 1987c. Effect of cimaterol on nitrogen retention and energy utilization in lambs. J. Anim. Sci., 65, Suppl. 1: 277 (Abstr.). 
Lai E., Rosen O.M., Rubin C.S., 1981. Differentiation-dependent expression of catecholaminestimulated adenylate cyclase. Roles of the $\beta$-receptor and $\mathrm{G} / \mathrm{F}$ protein in differentiating 3T3L1 adipocytes. J. Biol. Chem., 256, 12866-12874.

Lands A.M., Arnold A., McAuliff J.P.L, Luduena F.P., Brown T.G., 1967. Differentiation of receptor systems activated by sympathomimetic amines. Nature, 214, 597-598.

LeIBowitz S.F., 1970. Hypothalamic $\beta$-adrenergic "satiety " system antagonizes an $\alpha$-adrenergic " hunger" system in the rat. Nature, 226, 963-964.

LI J.B., JEFFERSON L.S., 1977. Effects of isoproterenol on amino acid level and protein turnover in skeletal muscle. Am. J. Physiol., 232, E243-E249.

MACGREGOR R.C., 1983. Growth promoters and their importance in ruminant livestock production. In: Recent advances in animal nutrition. Ed. by W. HARESIGN, Butterworths, London, pp. 161-177.

Machlin L.J., 1972 Effect of porcine growth hormone on growth and carcass composition of the pig. J. Anim. Sci., 35, 794-800.

Macrae J.C., Lobley G.E., Skene P.A., 1986. The effects of the $\beta$-adrenergic agonist clenbuterol on the energy expenditure and protein turnover of whether lambs. J. Anim. Sci., 63, Suppl. $1: 453$ (Abstr.).

Marsh B.B., 1975. Tenderness. In : Meat, Ed. by D.J.A. Cole and R.A. Lowrie, Butterworths, London, pp. 339-357.

McDowell G.H., 1983. Hormonal control of glucose homoeostasis in ruminants. Proc. Nutr. Soc. 42, $149-167$.

Mersmann H.J., 1987. Acute metabolic effects of adrenergic agents in swine. Am. J. Physiol., 252, E85-E95.

Mersmann H.J., Hu C.Y., Pond W.G., Rule D.C., Novakofski J.E., Smith S.B., 1987. Growth and adipose metabolism in young pigs fed cimaterol with adequate or low dietary protein. $J$. Anim. Sci., 64, 1384-1394.

Michaux C., Van Sichem-Reynaert R., Beckers J.F., de Fonseca M., Hanset R., 1982. Endocrinological studies on double muscled cattle : $\mathrm{LH}, \mathrm{GH}$, testosterone and insulin plasma levels during the first year of life. In : Muscle hypertrophy of genetic origin and its use to improve beef production. Ed. by J.W.B. KING and F. Menissier, M. Nijhoff, The Hague, pp. 350-367.

Miller M.F., Garcia D.K., Coleman M.E., Ekeren P.A., Smith S.B., 1986. Nonesterified and glyceride-fatty acid synthesis in bovine adipose tissue from heifers fed clenbuterol. J. Anim. Sci., 63, Suppl. 1: 236 (Abstr.).

Mrtchele H.H., 1962. Comparative nutrition of man and domestic animals. Volume I, Acad. Press, London, $701 \mathrm{pp}$.

Moser R.L., Dal.rymple R.H., Cornelius S.G., Pettigrew J.E., Allen C.E., 1986. Effect of cimaterol (CL 263,780) as a repartitioning agent in the diet for finishing pigs. J. Anim. Sci., 62, 21-26.

Muir L.A., Wien S., Duquette P.F., Olson G., 1985. Effect of the beta-adrenergic agonist L640,033 on lipid metabolism, growth and carcass characteristics of female broiler chickens. $J$. Anim. Sci., 61, Suppl. 1: 137 (Abstr.).

Orcutt A.L., Cline T.R., Mills S.E., 1986. Influence of beta-adrenergic agonists on sensitivity of mouse adipocytes to insulin. J. Anim. Sci., 63, Suppl. 1: 231 (Äbstr.).

Perkins S.N., Evans W.S., Thorner M.O., Cronin M.J., 1983. Beta-adrenergic stimulation of growth hormene release from perifused rat anterior pituitary cells. Neuroendocrinology, 37, 473-475.

Perkins S.W., Evans W.S., Thorner M.O., Gibbs D.M., Cronin M.J., 1985. $\beta$-adrenergic binding and secretory responses of the anterior pituitary. Endrocinology, 117, 1818-1825.

Prince T.J., Dalrymple R.H., Marple D.N., 1985. Effects of feeding cimaterol (CL 263,780) on performance and carcass characteristics of finishing pigs. J. Anim. Sci., 61, Suppl. 1: 301 (Abstr.).

Reeds P.J., Hay S.M., Dorwood P.M., Palmer R.M., 1986. Stimulation of muscle growth by clenbuterol : lack of effect on muscle protein biosynthesis. Br. J. Nutr., 56, 249-258. 
Reeds P.J., Palmer R.M., 1986. The role of prostaglandins in the control of muscle protein turnover. In : Control and manipulation of animal growth. Ed. by P.J. ButTERY, N.B. HAYNES and D.B. LindsaY, Butterworths, London, pp. 161-165.

Rickes E.L., Muir L.A., Duquette P.F., 1985. Effect of the beta-adrenergic agonist L-640,033 on growth and carcass composition of growing male rats. J. Anim. Sci., 61, Suppl. 1: 264 (Abstr.).

Ricks C.A., 1987. Partitioning of nutrient utilization in animal production. Proc. California Animal Nutrition Conference, pp. 7-20.

Ricks C.A., Baker P.K., Dalrymple R.H., Doscher M.E., Ingle D.L., Pankavich J., 1984 a. Use of clenbuterol to alter muscle and fat accretion in swine. Fed Proc., $43: 857$ (Abstr.).

Ricks C.A., Dalrymple R.H., Baker P.K., Ingle D.L., 1984b. Use of a $\beta$-agonist to alter fat and muscle deposition in steers. J. Anim. Sci., 59, 1247-1255.

Robelin J., Geay Y., 1978. Estimation de la composition chimique du corps entier des bovins à partir du poids des dépôts adipeux totaux. Ann. Zootech., 25, 159-167.

Rothwell N.J., Stock M., 1985. Modification of body composition by clenbuterol in normal and dystrophic (mdx) mice. Biosci. Rep., 5, 755-760.

Rothwell N.J., Stock M.J., Winter P.D.O'B, 1983. Acute effects of adrenoreceptor agonists on thermogenesis and brown adipose tissue activity in rats. $J$. Physiol., 340, 62P (Abstr.).

Rothwell N.J., Stock M.J., WINTER P.D.O'B, 1984. Effects of selective $\beta$-adrenoreceptor agonists on energy balance and body composition in the rat. Proc. Nutr. Soc., 43, 71A.

Sharpe P.M., Haynes N.B., Buttery P.J., 1986. Glucocorticoid status and growth. In : Control and manipulation of animal growth. Ed. by P.J. Buttery, N.B. HAYNes and D.B. Lindsay, Butterworths, London, pp. 207-222.

Siddle K., Hales C.N., 1975. Hormonal control of adipose tissue lipolysis. Proc. Nutr. Soc., 34, 233-239.

Sidhu K.S., Emery R.S., Parr A.F., Merkel R.A., 1973. Fat mobilizing lipase in relation to fatness in lambs. J. Anim. Sci., 36, 658-662.

SMITH P.B., Clark G.F., 1980. $\beta$-adrenergic receptor adenylate cyclase alterations during postnatal development of skeletal muscle. Biochim. Biophys. Acta., 633, 274-288.

SPENCER G.S.G., 1985. Hormonal systems regulating growth. A review. Livest. Prod. Sci., 12, 3146.

Spencer G.S.G., Garssen G.J., Hart I.C., 1983. A novel approach to growth promotion using auto-immunisation against somatostatin. I. Effects on growth and hormone levels in lambs. Livest. Prod. Sci., 10, 25-37.

Stiles G.L., Caron M.G., Lefkowitz R.J., 1984. $\beta$-adrenergic receptors : biochemical mechanisms of physiological regulation. Phys. Rev., 64, 661-743.

SWENnEN L., BAES M., Denef C., 1985. B-adrenergic stimulation of adenosine-3', 5'-monophosphate (c-AMP) accumulation and of prolactin and growth hormone secretion in rat anterior pituitary cell cultures. Neuroendocrinology, 40, 72-77.

Thiel L.F., Beermann D.H., Fishell. V.K., Crooker B.A., 1987. Effects of cimaterol on growth of hypophysectomized rats. Fed. Proc., 46, 1176 (Abstr.).

Thornton R.F., Tume R.K., Payne G., Larsen T.W., Johnson G.W., Hohenhaus M.A., 1985. The influence of the $\beta$ 2-adrenergic agonist, clenbuterol, on lipid metabolism and carcass composition of sheep. Proc. New Zealand Soc. Anim. Prod., 45, 97-101.

VAN Es A.J.H., 1976. Meat production from ruminants. In : Meat animals, Ed. by D. LiSTER, D.N. Rhodes, V.R. Fowler and H.F. Fuller, Plenum Press, Prestbury, pp. 391-401.

V AN Es A.J.H., 1977. The energetics of fat deposition during growth. Nutr. Metab., 21, 88-104.

VERNON R.G., 1981. Lipid metabolism in adipose tissue of ruminant animals. In : Lipid metabolism in ruminant animals. Ed. by W.W. Christie, Pergamon Press, Oxford, pp. 279-362.

VISEK W.J., 1978. The mode of growth promotion by antibiotics. J. Anim. Sci., 46, 1447-1469.

Welsh T.H., Smith S.B., Sutron M.R., Wagner K.A., 1987., Growth hormone releasing factor and clenbuterol regulation of bovine growth hormone secretion in vitro. J. Anim. Sci., 65, Suppl. $1: 279$ (Abstr.). 
WEST R.L., 1974. Red to white fiber ratios as an index of double muscling in beef cattle. J. Anim. Sci., 38, 1165-1175.

Williams P.E.V., Pagliani L., Innes G.M., Pennie K., 1986. The effect of the $\beta$-agonist clenbuterol on the composition of body gain of veal calves. British Society of Animal Production, Winter Meeting, Scarborough, 17-19 march 1986, Paper $\mathrm{n}^{\circ} 4$.

Wilson M.A., Forsberg N.E., Zhong C., Dalrymple R.H., Ricks C.A., 1987. Protein synthesis and degradation in sheep skeletal muscle : Effects of maturity and of dietary and medium cimaterol. J. Anim. Sci., 65, Suppl. 1: 251 (Abstr.).

Wu F.Y., Young C.R., Coleman M.C., Smith S.B., 1986. Total RNA and translatable mRNA levels in longissimus muscle from heifers fed diets containing a beta-agonist. J. Anim. Sci., 63, Suppl. 1: 237 (Abstr.).

Young V.R., 1980. Hormonal control of protein metabolism, with particular reference to body protein gain. In : Protein deposition in animals, Ed. by P.J. BuTTERY and D.B. LINDSAY, Butterworths, London, pp. 167-191.

Zeman R.J., Ludemann R., Etuinger J.D., 1987. Clenbuterol, a $\beta$ 2-agonist, retards atrophy in denervated muscles. Am. J. Physiol., 252, E152-E155. 